16. Konventsiz pro zakhist prav lyudini ta osnovopolozhnikh svobod vid 04 listopada 1950 r. RatifikovanoUkraïnoyu 17.07.1997. URL: https://zakon.rada.gov.ua/laws/show/995_004 (in Ukrainian).

17. Hornsbyv. Greece, 19 March 1997, par.40, ECHR 1997-II (in English).

18. Krutkov. Ukraine (no. 2), app. no. 33930/05, 27 November 2008, par. 19 (in English)

19. Zaytsev I. M. Problemy bor'by s sutyazhnichestvom $v$ arbitrazhe [Problems with abusing in arbatrary]: materialy resp. ekon.-prav. nauch. konf. Donetsk, 1972. S. 302 (in Russian).

20. Chechina N. A.,El'kindP. S. Ob ugolovno-protsessual'noy i grazhdanskoy protsessual'noy otvetstvennosti [About criminal and civil procedural responsibilities] Sov. gosudarstvo i pravo. 1973. № 9. S. 33-41 (in Russian).

21. Agarkov M. M. Problema zloupotrebleniya pravom v sovetskom grazhdanskom prave [Problems of abusing the procedural rights in soviet civil law] Izv. AN SSSR. Otd-ni eekonomiki i prava. 1946. № 6. S. 538 (in Russian)

S. Kravtsov, PhD (Law), Associate Prof.

Yaroslav Mudruy National Law University, Kharkiv, Ukraine
22. Bratus' S. N. O predelakh osushchestvleniya grazhdanskikh prav [About limits of civil rights implementation] (st. 5 Osnov grazhdanskogo zakonodatel'stva Soyuza SSR i soyuznykh respublik) .Izv. vuzov. Pravovedenie. 1967. № 3. S. 80-81 (in Russian)

23. Fursov D. A., Kharlamova I. V. Teoriya pravosudiya $v$ kratkom trekhtomnom izlozhenii po grazhdanskim delam [Theory of justice in brief three volumes edition of civil cases]. M.: Statut, 2009. 599 s. (in Russian).

24. Prikhod'ko I. A. Vosprepyatstvovanie razresheniyu del v arbitrazhnykh sudakh: aktual'nye voprosy sudebnogo pravoprimeneniya [Obstacles of cases resolution in arbitrary: current issues of judicial implementation]. M., 2006. 305 s. (in Russian).

Received: $05 / 03 / 2020$

1st Revision: $30 / 03 / 2020$

Accepted: $15 / 04 / 2020$

\title{
EXECUTIVE PROCEEDINGS AS THE FINAL STAGE OF THE TRIAL IN LIGHT OF ECHR PRACTICE AND ANTI-VIOLATION OF EXECUTIVE PROCEEDINGS PARTICIPANTS' PROCEDURAL RIGHTS
}

The paper explores the issues on the enforcement of judgments and its effectiveness, as well as the access to justice in civil cases. Based on the materials analyzed, the nature of the execution of civil decisions and enforcement proceedings in general is clarified. The abuse of law in the execution of court decisions is investigated. Based on the above analysis, the following types are distinguished: abuse by the claimant of the right to choose the place of enforcement proceedings commencing, the registration by the debtor at his place of residence (which is the sole property of the debtor that can be recovered) of a minor child, the cancellation of the results of electronic bidding through formal technical mistakes of the electronic auction organizer, abuse of the debtor's right to privacy, the initiation of parallel litigation by the debtor on the results of electronic bidding while the new owner sues the court to remove obstacles to the use of the premises and evictions, contemptuous attitude of enforcement proceedings participants to the executor while the complaint against the executor's actions is under the court's consideration.

The availability of justice in civil cases and the effectiveness of the mechanism for the protection of rights, freedoms and interests are directly linked to the observance of the requirement for irrevocable implementation of court decisions at the level of national law and the existence of effective enforcement mechanisms. The question of the nature of enforcement proceedings and their place in the legal system remains debatable in the civil procedural literature. As a rule, consideration of abuse of procedural rights is conducted in two directions, which do not exclude each other - from the point of view of the evaluation of abuse as a negative procedural phenomenon oranalysis of certain forms of abuse of procedural rights. There are also studies that deny the legitimacy of the design abuse of procedural rights.

Keywords: justice, enforcement proceedings, civil procedures, abuse of law.

Bulletin of Taras Shevchenko National University of Kyiv. Legal Studies, 2020; 1 (112): 43-48

УДК: 346.54

DOI: https:doi.org/10.17721/1728-2195/2020/1.112-8
ISSN 1728-2195

(C) Taras Shevchenko National University of Kyiv, Publishing center "Kyiv University", 2020

А. Рудковський, асп. ORCIDID 0000-0001-9648-8773 Київський національний університет імені Тараса Шевченка, Київ, Україна

\section{РОЛЬ ПРУДЕНЦІЙНОГО НАГЛЯДУ У СФЕРІ НАГЛЯДУ ЗА СТРАХОВОЮ ДІЯЛЬНІСТЮ В УКРАЇНІ}

Досліджено сучасний стан ринку страхових послуг в Україні та історію його становлення. Розглянуто наявні проблеми, що заважають прогресивному розвитку ринку та залученню інвестицій. Приділено увагу новітнім законодавчим змінам у державному регулюванні ринків фрінансових послуг (банківського і небанківських) одним регулятором (НБУ) $i$ доцільності його запровадження в небанківському фінансовому секторі та його подальшої ролі. Визначено основні важелі, завдяки яким Україна зможе отримати фрінансову систему, що відповідає міжнародним стандартам. Зосереджено увагу на положеннях Директиви ЄC Solvencyll та вимогах і стандартах, що закріплені в ній. Обґрунтовано доцільність запровадження всебічного пруденційного нагляду за страховиками, де визначено його особливості та механізми, завдяки яким він працює ефективно. Досліджено досвід краӥн, які вже запровадили такий нагляд. Визначено низку суттєвих змін, серед яких необхідно виділити прозору фінансову звітність, нові стандарти в наданні послуг, розширення функцій нагляду уповноваженого органу тощо, що дозволять запровадити належний захист прав споживачів фінансових послуе.

Визначено як низку переваг, так і недоліків сучасних змін та подальшої трансформації вітчизняного законодавства у сфері нагляду за страховою діяльністю до найкращих міжнародних стандартів. 3'ясовано, яких змін зазнає ринок страхування України та на що очікувати страховикам у найближчі роки, проаналізовано, яких втрат необхідно буде зазнати та що вони здобудуть у підсумку. Зосереджено увагу на захисті прав споживачів фінансових послуг задля унеможливлення настання подій, що мали місце на страховому ринку Украӥни на етапі його становлення.

Ключові слова: страхування, страховик, страхувальник, пруденційні норми, страховий нагляд, платоспроможність, небанківська фінансова установа.

Вступ. Станом натепер законодавство України проходить повноцінний етап оновлення та запровадження нових стандартів і норм, що відповідають міжнародному законодавству та законодавству Європейського Союзу. Наша країна перебуває у процесі реформ і тотальних змін, що мають змінити економічне життя держави та й загалом поліпшити інвестиційний клімат для міжнародних партнерів, оскільки значна кількість із них мають бажання щодо введення бізнесу на території України. Однак для того, щоб економічні показники українських підприємців були позитивними та бізнес почав відроджуватися, необхідні певні гарантії та середовище, яке зі свого боку надасть усі можливості для ведення господарської діяльності. Це нова система опо- 
даткування, лояльність банків і розумні відсотки для відкриття бізнесу, спрощена система реєстрації та ведення обліку, повна діджиталізація і запровадження останніх технологій. Усе ж будь-який вид господарської діяльності, беззаперечно, завжди є ризикованим i, на жаль, нині у підприємців немає остаточної впевненості в тому, що держава зможе їх захистити і надати всі гарантії та покрити можливі збитки. Саме таку впевненість за кордоном надають відповідні суб'єкти, які є головними учасниками ринку страхових послуг - страховики.

Страхова діяльність відіграє значну роль щодо розвитку ринкової економіки. Професійна діяльність суб'єктів страхового ринку забезпечує розвиток економічної сфери в будь-якій фінансово-розвиненій державі. Нині у країнах, де ринок страхових послуг пройшов етап становлення, прослідковується фінансова стабільність як державного бюджету, так й учасників такого ринку. Розвиток і функціонування страхової системи на належному рівні надасть змогу скоротити фінансові витрати 3 бюджету держави. У протилежних випадках держава відповідає самостійно додатковими фінансовими затратами із бюджетів різних рівнів. Задля уникнення зазначених випадків українському законодавцю необхідно звернути увагу на критичний і незадовільний стан норм національного законодавства, що врегульовують страхову діяльність. Запровадження нових і сучасних міжнародних вимог та оновлення нормативної бази надасть змогу обрати правильний шлях щодо розвитку страхової справи на теренах України.

Практика демонструє, що ринок страхування забезпечує безперервну роботу будь-якого сектора виробництва та не допускає його гальмування. Завдяки попиту на страхові послуги зазначений вид діяльності надає змогу акумулювати величезну суму коштів і подальше їхнє використання у сфері інвестицій та посідати провідне місце щодо відновлення та стабілізації економіки.

Історія становлення ринку страхових послуг. Після підписання Угоди про асоціацію між Україною та Європейським Союзом (ЄС) у 2014 р. Україна зобов'язалася дотримуватися всіх зазначених вимог щодо подальшої співпраці з країнами - учасницями ЄС. Однією з найважливіших вимог безпосередньо була і залишається натепер - оновлення та адаптація заходів щодо імплементації міжнародних норм у чинне законодавство України. Проте, на жаль, нині залишається чимало сорер, де необхідно якомога швидше запровадити модернізацію. Аналізуючи детальніше, варто наголосити на сорері страхування, а саме на їі нагляді та контролі.

Характеризуючи ринок страхування України, не можна стверджувати, що він не працює максимально ефективно та прозоро. Історія становлення ринку страхових послуг має певні негативні моменти, які залишили певні плями на його репутації та змушують споживачів сумніватися в доцільності обрання та використання такого сектора фінансових послуг. Історія розвитку страхового ринку України безпосередньо пов'язана 3 моментом формування та першими кроками його становлення. Науковці зазначали: головною проблемою того часу було те що: "За Радянського Союзу не було базового закону, який би регулював порядок ведення страхової діяльності. Оскільки страхова діяльність здійснювалась лише установами Держстраху й Індержстраху, які не мали повністю самостійного статусу, то не виникало потреби визначити законодавчі норми, які б на рівні законів встановлювали права й обов'язки цих суб'єктів. Окремі питання проведення страхової діяль- ності регулювалися Постановами ЦК КПРС та Ради Міністрів СРСР і УРСР, нормативними документами Держстраху та Укрдержстраху.

Улітку 1992 р. Укрдержстрах за участі низки провідних страхових компаній, утворених у 1990-1992 рр., подав до Кабінету Міністрів України перший законопроект "Про страхування", спрямований на узгодження позицій низки провідних міністерств і відомств. У грудні цього ж року цей проект після узгодження було повторно внесено на розгляд Кабінету Міністрів України. Оскільки згідно з рішенням Верховної Ради України в цей період Уряд дістав право видавати декрети, які мали статус законів, зазначений проект був прийнятий як декрет у травні 1993 р." [1, с. 3].

Проте згодом, після початку функціонування ринку страхових послуг у перші роки незалежності України було звернуто увагу на таку проблему, як доволі велику чисельність компаній-страховиків, що здійснювали страхову діяльність відповідно до чинного законодавства України на той час. Проблема було зосереджена на досить значній кількості випадків, коли під час настання страхових випадків і подальших страхових виплат страховики не мали достатньої кількості фінансів для погашення своїх зобов'язань, що були передбачені договорами.

Через деякий час ситуація набула поширення та стала катастрофічною, адже було викрито сотні компаній, що надавали свої послуги, не маючи взагалі жодних коштів та відповідного капіталу. 3 огляду на це необхідно було змінювати систему законодавства у сфері страхування та безпосередньо процедуру нагляду та контролю за страховиками.

Слід також зауважити, що в економічно розвинених країнах основними вхідними бар'єрами до страхового ринку є ліцензування і нормативи щодо статутного капіталу (платоспроможності страховиків). Зважаючи на невисоку вартість ліцензій і не значні вимоги регуляторних органів до страховиків, ліцензування виконувало вторинну роль при формуванні вхідних бар'єрів. Основним стримуючим чинником $€$ нормативи власного капіталу для страхових компаній. Незважаючи на негативні моменти, з ухваленням Декрету КМ України "Про страхування", а згодом і Закону України "Про страхування" - страховий ринок України все ж отримав реальний поштовх до подальшого становлення і розвитку [2, с. 350].

Отже, вирішуючи зазначене питання, необхідно звернути увагу на міжнародний досвід країн ЄС, що вже мають практику подолання та встановлення новітніх розвинених технологій щодо нагляду та контролю за фінансовими установами. I нині Україна намагається оновити та докорінно змінити систему чинного законодавства як про страхову діяльність, так і загалом.

Утворення СПЛІт. Вивчаючи зміни в напрямі реформування страхового законодавства, варто звернути увагу на зміну регулятора страхового ринку. 12 вересня 2019 р. було прийнято за основу і в цілому проєкт закону № 79-ІХ "Про внесення змін до деяких законодавчих актів України щодо вдосконалення функцій із державного регулювання ринків фінансових послуг"). Новий Закон України запроваджує частково консолідовану (інтегровану) модель регулювання фінансового ринку, за якої весь фінансовий сектор буде регулюватися двома регуляторами. Це буде зроблено шляхом передачі функцій Нацкомфінпослуг Національному банку і Національній комісії із цінних паперів та фондового ринку (НКЦПФР). 
Відповідно до Закону України "Про внесення змін до деяких законодавчих актів України щодо удосконалення функцій із державного регулювання ринків фрінансових послуг" № 79-ІХ від 12.09.2019 р., у Закон України "Про страхування" було внесено такі зміни:

1) у ст. 2: у ч. 8 слова "національною комісією, що здійснює державне регулювання у сфері ринків фрінансових послуг" замінено словами "Національним банком України"; у ч. 17 слова "за погодженням з Національним банком України" видалені;

2) у назві ст. 36 та 37 слова "національної комісії, що здійснює державне регулювання у сфері ринків фінансових послуг" замінено словами "Уповноваженого органу" [3].

3 огляду на зазначене вище НБУ з 01.07.2020 стане регулятором страхових, лізингових, фрінансових компаній, кредитних спілок, ломбардів і бюро кредитних історій, а НКЦПФР регулюватиме недержавні пенсійні фонди та фонди фрінансування будівництва. Отже, відбувається одночасна зміна та ліквідація Уповноваженого органу, який станом натепер очолює нагляд та безпосередній контроль за страховими організаціями (Нацкомфінпослуг).

У пояснювальній записці до проєкту Закону України "Про внесення змін до деяких законодавчих актів щодо удосконалення функцій із державного регулювання ринків фінансових послуг" (доопрацьований законопроєкт № 79-IX) надано обґрунтовану аргументацію стосовно необхідності ухвалення акта. Наголошується таке: система державного регулювання діяльності небанківських фрінансових установ та інших суб'єктів нагляду на ринках небанківських фінансових послуг не завжди має збалансований і системний характер. Правова база обмежується рамковим законодавством стосовно захисту прав споживачів, інвесторів, кредиторів, що разом із відсутністю спеціального законодавства щодо деяких небанківських фрінансових установ стримує інтенсивність розвитку ринків небанківських фінансових послуг, знижує їхню інвестиційну привабливість, деформує їхню роль у розвитку економіки України загалом.

Недостатня ефективність державного регулювання та нагляду, надмірна зарегульованість дозвільних процедур фінансовим установам та іншим піднаглядним організаціям необґрунтовано підвищують вартість надання фрінансових послуг споживачам.

Розроблення проєкту закону зумовлено необхідністю підвищення ефективності системи державного регулювання фінансових ринків шляхом унесення змін до чинного законодавства, спрямованих на припинення дублювання функцій національних регуляторів із ліцензування, контролю та нагляду, спрощення та прозорості ухвалення управлінських рішень у цій сорері, поліпшення умов ведення бізнесу з одночасним посиленням відповідальності суб'єктів ринку.

Безпосередньою метою законопроєкту є скорочення кількості регуляторних і контролюючих органів на ринках небанківських фрінансових послуг шляхом розподілу функцій Національної комісії, що здійснює державне регулювання у сфері ринків фрінансових послуг, між іншими органами, що здійснюють державне регулювання ринків фрінансових послуг.

Підвищення ефрективності державної регуляторної політики, функціональності нормативно-правових актів, спрямованих на створення дієвого механізму державного регулювання та нагляду, зниження витрат діяльності фінансових установ, спричинених надлишковим i неефективним державним регулюванням, забезпечення конкуренції на фрінансовому ринку, запобігання діяльності недобросовісних компаній, координованість із сучасними процесами реформування та дерегуляції економіки України сприятимуть активізації розвитку ринків небанківських фрінансових послуг [4].

На нашу думку, усе зазначене вище необхідно запровадити в життя та докорінно змінити вітчизняний ринок страхових послуг. Варто зосередити увагу безпосередньо на таких цілях, як створення дієвого механізму державного регулювання та нагляду, який, зі свого боку, забезпечить запобігання діяльності недобросовісних компаній та їхню появу в майбутньому.

Окремої уваги заслуговує думка голови Національно банку України Я. Смолія, який зауважив, що "Завдяки проведеній Національним банком реформі банківського сектора він сьогодні прозорий, докапіталізований, прибутковий та активно працює з населенням. СПЛІТ розширює можливості Національного банку для реалізації мандату із забезпечення фрінансової стабільності. Він надає нам змогу довести до логічного завершення реформу фінансового сектора, не обмежуючись лише банками і поширюючи вимоги щодо прозорості, надійності й ефективності і на небанківський фрінансовий сектор".

Цей закон дасть можливість забезпечити збалансований і системний підхід у напрямі ефективного розвитку небанківського фрінансового сектора, переходу від секторальної моделі регулювання до ефективнішої інтегрованої моделі та створить можливість для комплексного розвитку функції регулювання ринкової поведінки та захисту прав споживачів на фінансовому ринку.

Закон про СПЛІТ допоможе країні отримати фінансову систему, що відповідає міжнародним стандартам. 3 огляду на це ухвалення закону було однією із ключових вимог міжнародних партнерів України [5].

Роль та вимоги Solvency II. Беззаперечно, однією зі складових оновленої системи державного нагляду $є$ імплементація положень Директиви ЄC Solvency II, що охоплює значну кількість норм і передбачає чіткі вимоги щодо учасників страхового ринку ЄС. Серед них необхідно звернути увагу на норму ст. 27, що передбачає головну мету нагляду, де закріплено: "Держави-члени забезпечують, щоб наглядові органи мали необхідні ресурси і відповідний досвід, можливості та повноваження для виконання головної мети нагляду, а саме - захисту прав власників страхових полісів та бенефіціарів" [6].

Зазначена директива містить вимогу щодо реєстрації тих організацій, що займаються діяльністю у сорері страхування та перестрахування, і виключених зі сфери застосування цієї директиви. Також держави-члени можуть здійснювати пруденційний і юридичний контроль за діяльністю цих підприємств. Зазначений вид контролю тривалий час залишався невизначеним у вітчизняному законодавстві і фахівці намагалися виправити ситуацію.

О. Журавка у своєму дослідження зазначала, що, на думку фахівця-науковця М. Барта (Michael M. Barth) "У світовій практиці відсутнє усталене регуляторне визначення пруденційного нагляду". Основними міжнародними документами є директива Європейського парламенту та Ради № 2009/138/EC від 25 листопада 2009 р. щодо здійснення діяльності зі страхування та перестрахування (Solvency II). 
Поняття пруденційний нагляд розглядається як попередній, "ранній" нагляд, що дозволяє реєструвати потенційні можливості ускладнень і проблем у діяльності фрінансових установ, який базується на перевірці фрінансової звітності [7].

Однак нині стосовно страхового законодавства відбулися істотні зміни, адже проєкт нового Закону "Про страхування" містить термін пруденційні нормативи, у яких закріплено установлені нормативно-правовими актами уповноваженого органу нормативи, дотримання яких $\epsilon$ обов'язковим для страховиків, зокрема щодо перевищення розміру наявного регулятивного капіталу над розміром, установленим законодавством (достатності капіталу), відповідності термінів активів термінам виконання зобов'язань (ліквідності), ступеня диверсифрікації портфеля страхових зобов'язань і портфеля активів, якими представлені технічні резерви (диверсифікованості) [8].

Solvency II - це фундаментальний перегляд режиму достатності капіталу в галузі 291 страхування ЄС. Основною метою $є$ створення загальноєвропейських вимог до капіталу та стандартів управління ризиками, що будуть застосовуватись замість вимог Solvency I. Під дію Solvency II підпадатимуть усі страхові та перестрахові компанії з валовим доходом страховика більшим ніж $5 \mathrm{mлн} \mathrm{євро} \mathrm{або} \mathrm{технічними} \mathrm{резервами,} \mathrm{більшими}$ ніж 25 млн євро. Встановлення жорсткіших вимог достатності капіталу та ризик-менеджменту сприятиме зменшенню ризиків неплатоспроможності страховика, збитків споживача та дестабілізації ринку [9].

Вимоги Solvency II допоможуть встановити нові стандарти та набагато кращий рівень надання послуг для споживачів, оскільки відтепер система звітності та достатності капіталів компаній страховиків буде прозорою та змусить учасників ринку дотримуватись нових правил.

Solvency II складається з трьох компонентів (pillars):

- Компонент 1 визначає кількісні вимоги (напр., розмір капіталу, який повинен мати страховик).

- Компонент 2 встановлює вимоги до управління, ризиків та нагляду за страховиками.

- Компонент 3 зосереджується на вимогах щодо розкриття інформації та прозорості.

Компонент 1 передбачає наявність достатніх фрінансових ресурсів. Кількісні та якісні вимоги застосовуються до всіх компаній та охоплюють такі показники, як власні кошти, технічні резерви, розрахунок вимог до капіталу відповідно до Платоспроможності II (фактична маржа платоспроможності - the Solvency Capital Requirements (SCR) та нормативна маржа платоспроможності - Minimum Capital Requirements (MCR)).

Фактична маржа платоспроможності (SCR) - це капітал, необхідний для того, щоб (пере)страхова компанія змогла виконати свої зобов'язання протягом наступних 12 місяців із вірогідністю принаймні 99,5 \%. На додаток до капіталу SCR необхідно розрахувати вимогу щодо мінімального капіталу (MCR), яка представляє поріг, нижче якого втручається національний наглядовий орган (регулятор).

Встановлення жорсткіших вимог достатності капіталу та ризик-менеджменту сприятиме зменшенню ризиків неплатоспроможності страховика, збитків споживача та дестабілізації ринку [10].

На відміну від попередньої директиви (Solvency I) Solvency II надає змогу уповноваженим органам контролювати навіть і внутрішні системи страховиків. Її методологія уособлює в собі моделювання певних обста- вин та сценаріїв за допомогою комп'ютерного генерування, де кожен страховик може сформувати певні ситуації в майбутньому, які дадуть змогу дізнатися той самий необхідний рівень власного капіталу (SCR), та також провести аналіз і дізнатися реальний рівень фінансового стану страховика. Зазначена модель закріплює використання внутрішнього моделювання та засобів аналізу ризику, серед яких останнім часом особливим попитом у банківському секторі користується техніка стрес-тестування.

Нова концепція пруденційного регулювання вимагає уточнення стандартів оцінювання особливих ризиків страховика, змін у правилах обліку та звітності, наявності в органів нагляду за страховою діяльністю відповідних інструментів для відстеження "абсолютної платоспроможності" страхових компаній. Крім моніторингу виконання нормативної платоспроможності, розрахунку страхових резервів та інвестування, наглядовим органам необхідно перевіряти надійність систем управління, якість ведення бухгалтерського обліку, систем ризик-менеджменту та внутрішнього контролю.

Пруденційний нагляд стає невід'ємною складовою системи пруденційного регулювання. Наприклад, у більшості країн ЄС наглядовий процес базується на оцінці ризику, в інших - на розмірі певного параметра. Аналіз останніх публікацій і нормативних документів міжнародних організацій і державних регуляторів страхової діяльності дозволяє зробити висновок, що останнім часом збільшилася тенденція до нагляду на основі ризику (Risk-Based Supervision - RBS) разом із тенденцією до зростання конкуренції та надання регуляторами більшої свободи дій страховим компаніям. Діагностичні моделі оцінки ризику є частиною наглядового процесу в Австралії, Канаді, США, Нідерландах, Швейцарії [7, с. 142].

Іншими словами, новостворені норми нададуть можливості відповідному уповноваженому органу детальніше досліджувати й аналізувати всю необхідну інформацію стосовно діяльності страховиків та фрінансової звітності. Отже, буде введено нові критерії щодо оцінки ризиків, які заздалегідь нададуть певні сигнали в разі виникнення можливих загроз з боку страховиків.

Серед головних завдань Solvency II можемо виокремити таке:

- Завдяки новим змінам і критеріям стосовно оцінки капіталу страховика регулятор отримує реальну фінансову спроможність компаній та її ризики стосовно можливості невиконання зобов'язань перед страхувальниками;

- Оновлена система надасть змогу безпосередньо самим компаніям страховикам отримати реальні фрінансові показники стосовно капіталу якого буде достатньо задля виконання своїх обов'язків.

Більш того, для ефрективного та якісного ризикменеджменту необхідний ретельний аналіз внутрішніх ризиків компаній, а також ширше визначення терміна платоспроможності страховика.

Методологія щодо оцінки достатності рівня капіталу компанії страховика Solvency II ґрунтується на концепції Risk-Based Capital (ризикового капіталу) та на принципах Basel II, що використовуються у нагляді за діяльністю банків. Solvency II уособлює як кількісні, так і якісні складові. Зазначена концепція була вперше запроваджена у США та Канаді в 1992-1993 рр. та пізніше погоджена в Японії та в деяких інших країнах. Загальна вимога RBC полягає в такому: компанія має володіти 
капіталом для покриття кожного виду ризику. Капітал вираховується шляхом додавання добутків об'ємних показників на вагові коефіцієнти, що затверджуються органом страхового нагляду.

Насамперед, страхова компанія повинна фрормувати капітал на такому рівні, щоб вірогідність банкрутства протягом наступного року була не вищою ніж $1 / 200(0,05 \%)$.

По-друге, страхова компанія повинна мати внутрішню систему самостійної оцінки ризиків і рівня платоспроможності (Own Risk and Solvency Assessment ORSA), що має враховувати специфіку ризикового портфелю щодо кожної конкретної компанії. Зазначена система забезпечує інтереси як безпосередньо самих страховиків, допомагаючи ухвалювати правильні рішення при провадженні страхової діяльності, так і самих наглядових органів, полегшуючи розуміння ними ризикового портфелю компанії.

Крім цього, режим Solvency II базується на методиці річного VaR (SCR). Європейський страховий регулятор визначив, що достатній капітал повинен бути таким, що тільки в одному випадку із 200 страховик не зміг би виконати своїх зобов'язань у майбутньому році.

Національний банк України наголошує, що фрінансова стійкість та платоспроможність небанківських фінансових установ мають досягатися, насамперед, за рахунок пруденційного нагляду. Він передбачає встановлення певних кількісних і якісних вимог (пруденційних нормативів) до діяльності фінансових установ. Контроль за їхнім дотриманням дозволяє регулятору своєчасно виявити ризикову діяльність, ужити заходи оперативного втручання та в такий спосіб запобігти настанню негативних наслідків. Національний банк вбачає, що пруденційний нагляд є обов'язковим у страховому сегменті для кредитних спілок та інших кредитних установ, та фінансових установ, що надають послуги з переказу коштів.

У новій моделі регулювання пруденційні нормативи будуть специфічними для кожного сегменту ринку. Для більшої ефективності нагляду за страховими компаніями та кредитними установами Національний банк планує запровадити пропорційне регулювання, розподіливши установи на великі (системні), середні та малі. Відповідно, НБУ планує застосовувати до таких установ різні пруденційні нормативи залежно від того, які ризики для клієнтів та фрінансової системи може нести їхня неплатоспроможність. Основними критеріями для пропорційного регулювання будуть:

- абсолютний розмір залучених поворотних коштів або прийнятих на страхування ризиків;

- види діяльності;

- масштаби та складність бізнесу (географрічна присутність, кількість клієнтів тощо).

Це дозволить полегшити регуляторне навантаження на фінансові установи та підвищить конкурентне середовище для малих і середніх фінансових установ. 3 огляду на необхідність дієвого захисту страхувальників усі страхові компанії підлягатимуть пруденційному нагляду з боку регулятора. Для страхових брокерів та страхових агентів - юридичних осіб також встановлюватимуться певні пруденційні нормативи. Це відповідає загальноприйнятим світовим практикам та $є$ однією 3 вимог законодавства ЄС. Водночас лише великі страхові компанії будуть зобов'язані повністю виконувати вимоги Solvency II. Середні та малі страхові компанії зможуть використовувати спрощені вимоги Solvency II 3 урахуванням ризиків їхньої діяльності [11, с. 13].

Висновки. Підсумовуючи зазначене вище, необхідно звернути увагу на міжнародний досвід щодо впровадження Solvency II, задля того, щоб мати певну уяву, що очікує українських страховиків. Запровадження нових стандартів Solvency II для страхових компаній вимагає перебудови різних систем та процесів і неминуче призводить до зростання обсягу праці персоналу та додаткових витрат відповідних організацій. Також виникає необхідність залучення нових кваліфікованих фахівців у відповідних сфрерах, які зможуть забезпечити відповідність щодо нового режиму регулювання. На жаль не всі компанії матимуть змогу виконувати нові ухвалені нормативи, отже, зміни призведуть до скорочення кількості страховиків на ринку страхування. Це може стати як початком "кінця" багатьох учасників ринку, так і початком нарощення кількості ініційованих процедур злиття чи приєднання. До того ж необхідно передбачити подальше зростання цін на послуги, оскільки нові правила щодо звітності та контролю можуть завдати значних витрат компаніям страховикам.

Проте, слід зауважити, що в цьому випадку кількість переваг перевищує кількість недоліків. Оскільки тут приділяється значна увага вимогам споживачів страхових послуг - страхувальників. Саме цього не вистачало українському ринку страхування на етапі його становлення. Регулятор відтепер матиме більше прав щодо нагляду та контролю за учасниками страхового ринку. Прогнозується значне підвищення фінансовою стабільності у сфері страхування, повна прозорість стосовно звітності страховиків, високий рівень регулювання з боку НБУ. Усі ці зміни мають відродити довіру з боку страхувальників, оскільки нові стандарти змусять страховиків мати достатню кількість капіталу, відповідати за своїми зобов'язаннями в повному обсязі, надавати страхові послуг за новими міжнародними стандартами та також створити всі умови для приємного інвестиційного клімату, у якому іноземні інвестори відчували себе захищеними та були впевненими у своїх інвестиціях. Отже, страховий ринок України отримає шанс на відновлення та стрімкий розвиток, що передбачено програмою НБУ.

Список використаних джерел:

1. Соболь Р. Г. Правове регулювання страхової діяльності в Україні. Державне будівництво: Регіональне та галузеве управління. Харків, 2008. № 2. С. 1-9.

2. Козьменко О. В. Страховий ринок України у контексті сталого розвитку : монограф. Суми : ДВНЗ "УАБС НБУ", 2008. 350 с.

3. Про внесення змін до деяких законодавчих актів України щодо удосконалення функцій із державного регулювання ринків фінансових послуг : Закон України від 12.09.2019 р. № 79-ІХ (уведення в дію відбудеться 01.07.2020. URL: https://zakon.rada.gov.ua/laws/show/79-20?find= 1\&text=\%D1\%81\%D1\%82\%D1\%80\%D0\%B0\%D1\%85\%D0\%BE\%D0\%B2\% D1\%96+\%D0\%BA\%D0\%BE\%D0\%BC\%D0\%BF\%D0\%B0\%D0\%BD\%D1\% 96\%D1\%97\#w116 (дата звернення: 27.01.2020).

4. Пояснювальна записка до законопроєкту "Про внесення змін до деяких законодавчих актів щодо удосконалення функцій із державного регулювання ринків фінансових послуг" (доопрацьований законопроєкт № 1069). URL: https://w1.c1.rada.gov.ua/pls/zweb2/webproc34?id=\&pf3511= 66723\&pf35401=498573 (дата звернення: 27.01.2020).

5. Закон про спліт забезпечить прозорість, надійність та ефективність небанківського фінансового сектору. URL: https://bank.gov.ua/ news/all/zakon-pro-split-zabezpechit-prozorist-nadiynist-ta-efektivnistnebankivskogo-finansovogo-sektoru (дата звернення: 27.01.2020).

6. Директива 2009/138/€С Європейського парламенту та Ради від 25 листопада 2009 року про початок і ведення діяльності у сфері страхування і перестрахування (Платоспроможність II). URL: https://nfp.gov.ua/ files/docs/EU/\%D0\%94\%D0\%B8\%D1\%80\%D0\%B5\%D0\%BA\%D1\%82\%D0 \%B8\%D0\%B2\%D0\%B0\%202009_138.doc (дата звернення: 27.01.2020). 
7. Журавка О. С. Пруденційне регулювання страхової діяльності. Соціально-економічні проблеми сучасного періоду України. 2013. № 1. C. $139-146$.

8. Про страхування: проєкт Закону України від 29.08.2019 р. № 0964. URL: http://w1.c1.rada.gov.ua/pls/zweb2/webproc4 1?pf3511= 66558 (дата звернення: 27.01.2020).

9. Рудковський А. Є. Стандарти правового забезпечення економічної безпеки страховиків як суб'єктів господарювання в частині забезпечення платоспроможності. Господарське право та процес в умовах трансформації суспільних відносин : зб. мат. II Всеукраїнської наук.прак. конф., м. Кривий Ріг, 27 вересня 2019 р. 2019. С. 287-291.

10. Гнатюк М. М. Створення конкурентного середовища та зменшення ризиків неплатоспроможності на страховому ринку України / євроінтеграційний портал. URL: https://eu-ua.org/analityka/stvorennyakonkurentnogo-seredovyshcha-ta-zmenshennya-ryzykivneplatospromozhnosti-na\#2 (дата звернення: 27.01.2020).

11. Біла книга НБУ "Майбутнє у регулюванні небанківського фінансового сектору" (проєкт). URL: https://bank.gov.ua/files/TWwSwYdky YleLzN (дата звернення: 27.01.2020).

References:

1. Sobol' R. G. Pravove reguljuvannja strahovoi' dijal'nosti v Ukrai'ni State building: Regional and sectoral management]. Derzhavne budivnyctvo: Regional'ne ta galuzeve upravlinnja. 2008. Harkiv, № 2. S. 1-9 (in Ukrainian)

2. Koz'menko O.V. Strahovyj rynok Ukrai'ny u konteksti stalogo rozvytku [Ukraine's insurance market in the context of sustainable development]: monografija. Sumy: DVNZ "UABS NBU", 2008. 350 s. (in Ukrainian).

3. Pro vnesennja zmin do dejakyh zakonodavchyh aktiv Ukrai'ny shhodo udoskonalennja funkcij iz derzhavnogo reguljuvannja rynkiv finansovyh poslug : Zakon Ukrai'ny vid 12.09.2019 r. № 79-IX (vvedennja v diju, vidbudet'sja 01.07.2020. URL: https://zakon.rada.gov.ua/laws/show/7920? find $=1 \&$ text $=\% \mathrm{D} 1 \% 81 \% \mathrm{D} 1 \% 82 \% \mathrm{D} 1 \% 80 \% \mathrm{D} 0 \% \mathrm{~B} 0 \% \mathrm{D} 1 \% 85 \% \mathrm{D} 0 \% \mathrm{BE} \%$ D0\%B2\%D1\%96+\%D0\%BA\%D0\%BE\%D0\%BC\%D0\%BF\%D0\%B0\%D0\% $\mathrm{BD} \% \mathrm{D} 1 \% 96 \% \mathrm{D} 1 \% 97 \# \mathrm{w} 116$ (in Ukrainian).

4. Pojasnjuval'na zapyska do zakonoproektu "Pro vnesennja zmin do dejakyh zakonodavchyh aktiv shhodo udoskonalennja funkcij iz derzhavnogo reguljuvannja rynkiv finansovyh poslug" (dooprac'ovanyj zakonoproekt № 1069) [Explanatory Note to the draft Law "On Amendments to Certain Legislative Acts on Improving Functions in State Regulation of Financial Services Markets"]. URL: https://w1.c1.rada.gov.ua/pls/zweb2/ webproc34?id=\&pf3511=66723\&pf35401=498573 (in Ukrainian)

\section{A. Rudkovskii, PhD Student}

Taras Shevchenko National University of Kyiv, Kyiv, Ukraine
5. Zakon pro split zabezpechyt' prozorist', nadijnist' ta efektyvnist' nebankivs'kogo finansovogo sektoru [The Split Law will ensure the transparency, reliability and efficiency of the non-banking financial sector]. URL: https://bank.gov.ua/news/all/zakon-pro-split-zabezpechit-prozorist-nadiynistta-efektivnist-nebankivskogo-finansovogo-sektoru (in Ukrainian).

6. Dyrektyva 2009/138/JeS Jevropejs'kogo Parlamentu ta Rady vid 25 lystopada 2009 roku pro pochatok i vedennja dijal'nosti u sferi strahuvannja i perestrahuvannja (Platospromozhnist' II). URL: https://nfp.gov.ua/files/docs/EU/\%D0\%94\%D0\%B8\%D1\%80\%D0\%B5\%D0\% BA\%D1\%82\%D0\%B8\%D0\%B2\%D0\%B0\%202009_138.doc (in Ukrainian).

7. Zhuravka O. S. Prudencijne reguljuvannja strahovoi' dijal'nosti [Prudential regulation of insurance activity]. Social'no-ekonomichni problemy suchasnogo periodu Ukrai'ny. 2013 r. №1. S.139-146 (in Ukrainian).

8. Pro strahuvannja: proekt Zakonu Ukrai'ny vid 29.08.2019 r. № 0964. URL: http://w1.c1.rada.gov.ua/pls/zweb2/webproc4 1?pf3511=66558 (in Ukrainian).

9. Rudkovs'kyj A. Je. Standarty pravovogo zabezpechennja ekonomichnoi' bezpeky strahovykiv jak sub'jektiv gospodarjuvannja v chastyni zabezpechennja platospromozhnosti [Standards for legal assurance of economic security of insurers as economic entities in terms of solvency]. Gospodars'ke pravo ta proces v umovah transformacii' suspil'nyh vidnosyn: zbirnyk materialiv drugoi' Vseukrai'ns'koi' nauk.-prak. konf., m. Kryvyj Rig, 27 veresnja 2019 r. S. 287-291 (in Ukrainian)

10. Gnatjuk M. M. Stvorennja konkurentnogo seredovyshha ta zmenshennja ryzykiv neplatospromozhnosti na strahovomu rynku Ukrai'ny [Creating a competitive environment and reducing insolvency risks in the Ukrainian insurance market] / Jevrointegracijnyj Portal. URL: https://eu-ua.org/analityka/stvorennya-konkurentnogo-seredovyshchata-zmenshennya-ryzykiv-neplatospromozhnosti-na\#2 (in Ukrainian).

11. Bila knyga NBU "Majbutnje u reguljuvanni nebankivs'kogo finansovogo sektoru" (projekt) [NBU White Paper "The Future in Regulation of the Non-Banking Financial Sector"]. URL: https://bank.gov.ua/files/ TWwSwYdkyYleLzN (in Ukrainian)

Received: $27 / 01 / 2020$

1st Revision: $19 / 02 / 2020$

Accepted: $15 / 03 / 2020$

\section{THE ROLE OF PRUDENTIAL SUPERVISION IN THE FIELD OF INSURANCE SUPERVISION IN UKRAINE}

The article investigates the current state of the insurance market in Ukraine and the history of its formation. The existing problems that hinder the progressive development of the market and attract investment are considered. Attention is paid to the latest legislative state regulation of financial services markets (banking and non-banking) by one regulator (NBU) and the expediency of its introduction in the non-banking financial sector and its further role. The main levers by which Ukraine will be able to obtain a financial system that meets international standards have been identified. The focus is on the provisions of the EU Solvency II Directive and the requirements and standards set out therein. It also substantiates the feasibility of securing prudential supervision of insurers, which defines its peculiarities and mechanisms by which it operates effectively. The experience of countries that have already introduced this type of surveillance is explored. A number of significant changes have been identified, among which are the following: transparent financial statements, new standards for service provision, extension of oversight functions of the Authorized Body, etc., which will allow for the proper protection of the rights of consumers of financial services.

Purpose: to analyze the international norms and standards according to which insurers operate within the European Union. Do the research on the EU Directive (Solvency II) and the feasibility of its implementation in national legislation. The advantages and disadvantages of prudential supervision of insurers have been identified.

Methods: General and specific cognition methods have been involved in the writing of the work. Historical method, comparative-legal method, system-structural analysis method and formal-logical methods have been used as the basis of the research methodology.

Results: justification for the introduction of a new transparent financial reporting system in the future; the need to create a new internal insurer risk assessment system and new capital adequacy requirements.

Conclusions: A number of advantages and disadvantages of current changes and further transformation of domestic legislation in the field of insurance supervision to the best international standards have been identified. It examines what changes the insurance market of Ukraine is going through and what to expect from insurers in the coming years, what costs will have to be incurred and what they will receive as a result. The focus is on protecting the rights of consumers of financial services to prevent events occurring in the insurance market more than 25 years ago.

Keywords: insurance, insurer, insurer, prudential norms, insurance supervision, solvency, non-bank financial institution. 